\title{
Rapeseed glucosinolates and iodine in sows affect the milk iodine concentration and the iodine status of piglets*
}

\author{
Friedrich Schöne ${ }^{1} \dagger$, Matthias Leiterer ${ }^{1}$, Horst Hartung ${ }^{1}$, Gerhard Jahreis ${ }^{2}$ and Frank Tischendorf ${ }^{2}$ \\ ${ }^{1}$ Agricultural Institution of Thuringia (Jena), D-07743 Jena, Naumburger Straße 98, Germany \\ ${ }^{2}$ Friedrich-Schiller-University (Jena), Institute of Nutrition, D-07743 Jena, Dornburger Straße 24, Germany
}

(Received 16 February 2000 - Revised 19 September 2000 - Accepted 3 December 2000)

\begin{abstract}
I in the chain sow diet $\rightarrow$ blood serum of sow $\rightarrow$ sow milk $\rightarrow$ piglet serum was investigated in two experiments with a total of eighty-one sows and their piglets. In experiments conducted during the last trimester of gravidity and the $28 \mathrm{~d}$ of lactation, diets with glucosinolates $(1.9 \mathrm{mmol} / \mathrm{kg}$ diet via $100 \mathrm{~g}$ ground rapeseed/ $\mathrm{kg}$ diet (Expt 1$)$ and 2.1 and $4.2 \mathrm{mmol} / \mathrm{kg} \mathrm{diet} \mathrm{via}$ 75 and $150 \mathrm{~g}$ rapeseed press cake/kg diet (Expt 2)) were compared with control groups without rapeseed products. From 0 to $600 \mu \mathrm{g} \mathrm{I} / \mathrm{kg}$ was added to sow diets during lactation. Diets without supplementary I decreased the I concentration particularly in milk and piglet serum. The presence of rapeseed and rapeseed press cake were indicated by a thiocyanate concentration increase, mainly in sow serum. The diets with glucosinolates decreased the milk and piglet serum I concentration. Spot urine and faeces samples from sows eating the rapeseed-press cake diets had increased I concentration. The sows' serum I and thyroxine did not respond to glucosinolates (Expt 1) or these diets caused an increase in concentration (Expt 2). Both these criteria seem unsuitable for the diagnosis of I status of adult animals. Glucosinolates and their degradation compounds may affect the thyroid and the mammary glands resulting in lower I milk transfer and higher renal and intestinal I excretion.
\end{abstract}

Rapeseed: Milk iodine: Sows: Piglets

Glucosinolates, also known as thioglucosides, are present in cruciferous vegetables such as cabbage, cauliflower or Brussels sprouts and in rapeseed feeds. Glucosinolates can be cleaved by the enzyme myrosinase (thioglucoside glucohydrolase) which is present in the same plants as the glucosinolates but is separated from them (Maheshwari et al. 1981). Any destruction of the plant cell brings the substrate and the enzyme together creating isothiocyanates, oxazolidinethiones, nitriles, thiocyanates and further compounds of glucosinolate degradation. Some gastrointestinal microbes have a myrosinase-like activity (Oginsky et al. 1965) causing intestinal glucosinolate degradation (Rowan et al. 1991) and glucosinolate degradation products can be absorbed. However, an increase in blood serum thiocyanate concentration could only be found in different species (Paik et al. 1980; Schöne et al. 1990, 1997c) after feeding rapeseed meal (solvent extracted), rapeseed press cake or ground rapeseed.

Low quantities of glucosinolates or their degradation products may give specific taste and flavour effects
(Fenwick et al. 1983) and benefit human health (Jongen, 1996). At higher dietary levels, they impair food intake and growth. Depressed feed consumption and growth have been shown in pigs, where the diet included high-glucosinolate rapeseed meals (100-150 mmol glucosinolates/kg defatted matter). However, high quantities of low glucosinolate meals based on ' 00 ' varieties or treatment can also negatively affect pig performance (Rundgren, 1983; Bell, 1984; Bourdon \& Aumaitre, 1990; Schöne et al. 1997a).

Glucosinolates are I antagonists. In eastern Germany until 1986, swine diets containing high-glucosinolate rapeseed meal were not supplemented with I and pigs suffered from hypothyroidism, evident as cretinism, changed body proportions, myxoedema and severe goitre (Lüdke \& Schöne, 1988). In pregnant sows feeding highglucosinolate rapeseed feeds without I addition accelerated and strengthened the incidence of I-deficiency disease. This was indicated by prolonged pregnancy and piglets being stillborn with impaired viability (Schuld \& Bowland, 1968; Devilat \& Skoknic, 1971; Gürtler et al. 1982).

\footnotetext{
Abbreviations: $\mathrm{T}_{3}$, triiodothyronine. $\mathrm{T}_{4}$, thyroxine.

* Presented in part at the 3rd international workshop on 'Antinutritional factors in legume seeds and rapeseed', Wageningen, the Netherlands (Schöne et al. 1998b).

† Corresponding author: Dr Friedrich Schöne, fax +49 3641463 630, email b8scfr@rz.uni-jena.de
} 
Sometimes the piglets were hairless or oedematous, but they always had an enlarged thyroid, and thyroxine $\left(\mathrm{T}_{4}\right)$ could not be found in the serum of piglets or of their mothers (Schöne et al. 1986). Dosing with I and thyroid hormone increased serum $\mathrm{T}_{4}$ concentration and cured the Ideficiency disorder. However, depressed performance and poor animal health still occurred. Therefore, it was recommended that high-glucosinolate rapeseed meal should be excluded from sow rations. Low-glucosinolate rapeseed meals seemed to have better potential for use in sow diets (Danielsen et al. 1987). However, there were still adverse effects of meals with a reduced glucosinolates content on the survival of embryos and piglets and on the serum $\mathrm{T}_{4}$ concentration of the piglets (Etienne \& Dourmad, 1994).

Undetectable $\mathrm{T}_{4}$ serum concentrations and I-deficiency disorder are based on emptying the thyroid I depot from $>500 \mu \mathrm{g} \mathrm{I} / \mathrm{g}$ to $\leq 100 \mu \mathrm{g} \mathrm{I} / \mathrm{g}$. This was shown in growing pigs fed rapeseed meal for a long period $(10 \mathrm{mmol}$ glucosinolates $/ \mathrm{kg}$ diet) without added dietary I (Schöne et al. 1990).

The range of thyroid I depends on peroxidase action oxidising iodide taken up from the blood to elemental I, which binds to the tyrosyl residues and hormone precursors of thyroglobulin respectively. The presence of glucosinolates changes the action of thyroid peroxidase. According to an in vitro assay of Kohler et al. (1988), the enzyme oxidises oxazolidinethiones and probably further glucosinolate degradation products and thus uses elemental I. I will be reduced to iodide, which cannot be taken up by thyroglobulin and this results in a decrease in thyroid I concentration.

The objectives of the present two experiments were to evaluate the sow and piglet response to dietary glucosinolates combined with different concentrations of I. The glucosinolate content of the diets was varied by using ground rapeseed (Expt 1) or rapeseed press cake (Expt 2). In both cases, the rape varieties were of the ' 00 ' type. During lactation, sow I supply comprised 0 (no I addition), $150 \mu \mathrm{g}$ supplementary I/kg diet (the National Research Council (1998) recommends $140 \mu \mathrm{g} \mathrm{I} / \mathrm{kg}$ diet), 300 and $600 \mu \mathrm{g}$ supplementary I/kg diet (the Agricultural Council (1981) recommends 400, and the Gesellschaft für Ernährungsphysiologie (1987) $500 \mu \mathrm{g}$ supplementary I/kg diet). Animal response criteria measured were feed intake and rearing results, the serum concentration of thiocyanate ions $\left(\mathrm{SCN}^{-}\right)$, I and thyroid hormones, and the colostrum and milk I content. In Expt 2 spot urine and faeces samples were taken from sows to determine the I concentration dependent on glucosinolate and I ingestion. Until now, I has rarely been measured in the excreta of farm animals. This contrasts with studies on human subjects (Thomas, 1995), which use urine I level to classify I supply status.

\section{Materials and methods}

\section{Rapeseed and rapeseed press cake tested}

The rapeseed used was from a single batch and the press cake was produced from another single batch. Seed and press cake characteristics were determined prior to each experiment and are given later (for descriptions of analyses see later).

The rapeseed, winter cultivar Madora (breeder Saatzucht Hans Lembke GmbH Malchow, Poel, Germany), contained (g/kg DM): crude protein 224, diethyl ether extract 444, crude fibre 89, ash 45.

Total glucosinolate concentration was $21.4 \mathrm{mmol} / \mathrm{kg}$ DM. This comprised (mmol/kg): gluconapin $4 \cdot 3$, glucobrassicanapin $1 \cdot 1$, progoitrin $11 \cdot 6$, 4-hydroxyglucobrassicin $3 \cdot 0$, pronapoleiferin $0 \cdot 4$, other glucosinolates $1 \cdot 0$. No glucosinolate degradation products were detected.

Seed was crushed as a mixture with barley using a hammer mill with a $2.7 \mathrm{~mm}$ screen.

Rapeseed press cake, originating from a seed batch of the winter cultivar Karola (breeder Semundo, Rellingen, Germany), was pressed in a screw press (MONFORTS Komet CA59, Mönchengladbach, Germany). It contained (g/kg DM): crude protein 323, diethyl ether extract 188, crude fibre 154, ash 59. According to digestibility experiments, rapeseed press cake with a similar fat content provided 14.1 MJ metabolisable energy/kg DM which is similar to the energy content of barley (Lüdke \& Schöne, 1994).

The total glucosinolate concentration was $31.5 \mathrm{mmol} / \mathrm{kg}$ DM. This comprised ( $\mathrm{mmol} / \mathrm{kg})$ : gluconapin $6 \cdot 5$, progoitrin 18.4, 4-hydroxyglucobrassicin 4.5, glucobrassicin 1.2, pronapoleiferin $0 \cdot 6$, other glucosinolates $0 \cdot 3$. Again no glucosinolate degradation products were detected.

\section{Animals and experimental diets}

In 1994 and 1997 the two experiments were conducted during the last trimester of pregnancy and $28 \mathrm{~d}$ of lactation with eighty-one sows (German Landrace $\times$ Large White). In Expt 1 there were thirty-six animals, divided into three groups with twelve animals per group, in Expt 2 there were fourty-five sows, in three groups of fifteen sows.

The pregnant sows at mean stage of gestation $80 \mathrm{~d}$ in Expt 1, and $86 \mathrm{~d}$ in Expt 2 were randomly allocated to the three homogenous groups in each experiment. Allocation was based on parity number and their live weight. The majority of sows represented the 2 nd to the 6th parity. In Expt 1 three of the twelve sows per group were gilts (primiparous sows), in Expt 2 six of the fifteen sows per group. The sows had been artificially inseminated with sperm from Pietrain boars at the same time. This was after synchronisation using pregnant mare serum gonadotropin and human chorionic gonadotropin. During gestation, animals were housed in individual stalls on partially slatted floors. Sows were transferred to farrowing units at least $4 \mathrm{~d}$ before the birth. Litters were held in pens on partially slatted floors with individual stalls for sows and a heated plate as lying area for the piglets.

Diets for both experiments (Table 1) were isonitrogenous (180 g crude protein $/ \mathrm{kg}$ diet); those of Expt 2 (groups I-III) also had the same metabolisable energy content. In Expt 1, in group 2 rapeseed oil was included to reach fat and metabolisable energy content similar to the diet with ground rapeseed (group 3). Further details of diets, e.g. their fatty acid profiles, were published (Schöne et al. $1998 a$ ). During gestation, an I dose of $150 \mu \mathrm{g} / \mathrm{kg}$ diet was 
Table 1. Composition of experimental diets in Expt 1 and Expt 2 ( $\mathrm{g} / \mathrm{kg}$ diet)

\begin{tabular}{|c|c|c|c|c|c|c|}
\hline \multirow[b]{2}{*}{ Group.... } & \multicolumn{3}{|c|}{ Expt $1^{*}$} & \multicolumn{3}{|c|}{ Expt 2† } \\
\hline & $\begin{array}{c}1 \\
\text { Control }\end{array}$ & $\stackrel{2}{2}$ Rapeseed oil & $\stackrel{3}{\text { Ground rapeseed }}$ & $\begin{array}{c}\text { I } \\
\text { Control }\end{array}$ & $\begin{array}{c}\text { II } \\
\text { Rapeseed press cake }\end{array}$ & $\begin{array}{c}\text { III } \\
\text { Rapeseed press cake }\end{array}$ \\
\hline Glucosinolate content $\mathrm{mmol} / \mathrm{kg} \ldots$ & 0 & 0 & 1.9 & 0 & $2 \cdot 1$ & $4 \cdot 2$ \\
\hline \multicolumn{7}{|l|}{ Ingredients } \\
\hline Solvent extracted soyabean meal & 220 & 240 & 195 & 220 & 185 & 145 \\
\hline Rapeseed oil & 5 & 40 & - & - & - & - \\
\hline Ground rapeseed & - & - & 100 & - & - & - \\
\hline Rapeseed press cake & - & & - & - & 75 & 150 \\
\hline Barley & 755 & 700 & 685 & 760 & 720 & 685 \\
\hline Mineral vitamin premix $\ddagger$ & 20 & 20 & 20 & 20 & 20 & 20 \\
\hline \multicolumn{7}{|l|}{ Analysed constituents } \\
\hline DM & 885 & 887 & 890 & 887 & 886 & 890 \\
\hline Crude protein & 183 & 177 & 182 & 197 & 186 & 191 \\
\hline Diethyl ether extract & 29 & 56 & 58 & 26 & 38 & 49 \\
\hline Crude fibre & 47 & 51 & 59 & 58 & 62 & 65 \\
\hline Ash & 58 & 59 & 59 & 55 & 50 & 52 \\
\hline Metabolisable energy $(\mathrm{MJ} / \mathrm{kg}) \S$ & $12 \cdot 6$ & $13 \cdot 3$ & $13 \cdot 0$ & $12 \cdot 6$ & $12 \cdot 6$ & $12 \cdot 6$ \\
\hline
\end{tabular}

the same for all animals. During lactation the I dose differed. In Expt 1, the twelve sows of each group were subdivided into three subgroups with four sows per subgroup each as follows: (A) no I addition; (B) $150 \mu \mathrm{g}$ supplementary I/kg diet; (C) $300 \mu \mathrm{g}$ supplementary I/kg diet.

In Expt 2 the fifteen sows of each group were subdivided into three subgroups of five sows as follows: (a) $150 \mu \mathrm{g}$ supplementary $\mathrm{I} / \mathrm{kg}$ diet; (b) $300 \mu \mathrm{g}$ supplementary $\mathrm{I} / \mathrm{kg}$ diet; (c) $600 \mu \mathrm{g}$ supplementary $\mathrm{I} / \mathrm{kg}$ diet.

The I was provided as KI bound to casein. This preparation was found to be highly stable (Schöne et al. 1997c). The I content of the feeds and diets used were determined prior to the experiments and are given later (for a description of the analysis see the next part of this section, p. 661). Barley, rapeseed and rapeseed press cake had I concentrations below the detection limit of $<20 \mu \mathrm{g} / \mathrm{kg}$. In the soyabean meal and in the mineral vitamin premix 51 and $310 \mu \mathrm{g} \mathrm{I} / \mathrm{kg}$ were detected respectively. The diet without I addition (Expt 1) contained $25 \mu \mathrm{g} \mathrm{I} / \mathrm{kg}$. In the diets with $150 \mu \mathrm{g}$ supplementary $\mathrm{I} / \mathrm{kg}$, total I concentrations of 132 (Expt 1) and $210 \mu \mathrm{g} / \mathrm{kg}$ (Expt 2) were detected. In the diets with $300 \mu \mathrm{g}$ supplementary I/kg total concentration of 270 (Expt 1) and $320 \mu \mathrm{g} / \mathrm{kg}$ (Expt 2) were detected. The diets with $600 \mu \mathrm{g}$ supplementary I/kg (Expt 2) contained $680 \mu \mathrm{g} \mathrm{I} / \mathrm{kg}$.

Until the birth, each sow received $39 \mathrm{MJ}$ metabolisable energy/d. This feeding level was $20 \%$ greater than recommended (Gesellschaft für Ernährungsphysiologie, 1987) and was a concession to large-frame animals. During lactation feeding was ad libitum. From the 5th day piglets received creep feed which consisted of wheat, soyabean meal, whey powder, casein, rapeseed oil and mineral vitamin premix without supplementary I (210 g crude protein and $15 \mathrm{~g}$ lysine/kg diet).

\section{Investigation criteria, samples and analyses}

The sows were weighed at the beginning of the experiments, and on transfer to the farrowing unit (109th day of pregnancy), at $48 \mathrm{~h}$ post-partum and at weaning. Piglets were weighed at birth and at weaning. The thyroid glands of stillborn piglets and those that died up to $24 \mathrm{~h}$ postpartum were removed and weighed. Feed was weighed daily for each sow. Creep feed was weighed for each litter. Creep feed refusals were recorded after drying at $60^{\circ} \mathrm{C}$.

Colostrum (about $30 \mathrm{ml}$ ) was milked at birth or immediately after. On the 27th day of lactation the same quantity of mature milk was sampled after injection with oxytocin (29 IU/sow intramuscularly). Blood was taken from sows and two piglets per litter by vena cava cranialis or vena jugularis puncture, shortly after sampling the mature milk.

In Expt 2 spot urine and faeces samples were taken from sows of the control group (without rapeseed press cake) and the group with the $150 \mathrm{~g}$ rapeseed press cake/kg diet. Sampling of spot urine took place on lactation day 26 for 14 h (06.00-20.00 hours) of Expt 2 using special highgrade steel scoops equipped with $1 \mathrm{~m}$ long handles. Faeces were sampled immediately after their emersion, lyophilised and ground for I and DM determination.

In both experiments, the DM, crude protein, diethyl ether extract, crude fibre and ash content was determined in both feed ingredients and diets (Bassler \& Buchholz, 1993). Glucosinolates were measured by HPLC with sinigrin as the internal standard (European Community, 1990). Aglucones were determined by a temperature-programmed GC and by MS with phenylisothiocyanate as an internal standard (Lange et al. 1986). The I contents of the feed ingredients and the diets of both experiments and of lyophilised faeces (Expt 2) were measured by intracoupled 
plasma-MS (ICP-MS ELAN 6000; Perkin Elmer, Überlingen, Germany) after matrix disintegration and solution in tetramethylammonium hydroxide (Fecher et al. 1998).

For analysis $1 \mathrm{ml}$ tetramethylammonium hydroxide (250 g/l; Tamapure-AA, Tama Chemicals, Kawasaki Lab., Osakai, Japan) was added to the mix of 200$500 \mathrm{mg}$ solid sample and $5 \mathrm{ml}$ of distilled deionised water in a closed $50 \mathrm{ml}$ polypropylene gas-tight tube. After disintegration for $3 \mathrm{~h}$ at $80^{\circ} \mathrm{C}$ and cooling to room temperature, $19 \mathrm{ml}$ distilled deionised water was added and centrifuged for $15 \mathrm{~min}$ at $4000 \mathrm{~g}$. The supernatant fraction was mixed with distilled deionised water to reach an expected concentration meeting one of three calibration solution series: (1) 0,1,2 and $5 \mu \mathrm{g} I / l i t r e$; (2) 0, 5, 10 and $20 \mu \mathrm{g} \mathrm{I} /$ litre; (3) 0, 25, 50 and $100 \mu \mathrm{g} \mathrm{I} /$ litre.

As standard solutions, urine or milk samples were prepared with KI (ultrapure, Johnson Matthey ALFA Products, Karlsruhe, Germany). The freshly prepared KI standards were added to the liquid feed or faeces samples, which were injected into a plasma of intracoupled plasmaMS. Te (Spex, Grasbrunn, Germany) (100 $\mu \mathrm{g} / \mathrm{l})$ was used as the internal standard. The method had a recovery rate of 95-109\% and a detection limit of $1 \mu \mathrm{g}$ I/litre milk or serum. Results were confirmed using the certified standard BCR N 151 (Community Bureau of Reference). In this 'spiked skimmed milk powder' the recovered corresponded to the certified I concentration (103\% from spiking).

The $T_{4}$ and triiodothyronine $\left(T_{3}\right)$ concentration in serum was measured by radioimmunoassay using a commercially available kit (Kodak, Amersham, Bucks., UK). Thiocyanate concentration in serum, colostrum, and milk were determined by HPLC (Rudolph, 1993). I was measured as previously described by intracoupled plasma-MS using an addition calibration. Samples were directly diluted (sample - double-distilled water $(1: 9, \mathrm{v} / \mathrm{v}))$, mixed with the KI standard and directly injected by cross-flow sprayer into the plasma of the intracoupled plasma-MS. The level of creatinine in urine was based on Jaffé reaction (Thomas, 1995).

\section{Statistical methods}

All data were analysed with the SAS software package (version 6.11, Statistical Analysis System Institute, Heidelberg, Germany). The results are given as mean values with their (pooled) standard error. From the results of previous pig experiments (Schöne et al. 1997b) no effect of I supplementation could be expected on animal weights, feed intake and piglet number due to the mobilisation of I from thyroid depots. Therefore, the data were analysed by oneway ANOVA, computing the probability level of the factor glucosinolate. Thyroid weight of stillborn piglets and I colostrum concentration, which could be affected only by glucosinolates (the dietary I did not differ during pregnancy), were treated in the same way. Data for serum I and thyroid hormone status and milk status at the end of lactation were analysed by two-way ANOVA with the factors glucosinolate, I dosage and the interaction glucosinolate $\times$ I dosage. Group means were compared using the Newman-Keuls test (Steel \& Torrie, 1980).

\section{Results}

Body weight and feed intake of sows and rearing results

In Expt 1 there was a significantly increased feed intake of the rapeseed oil diet. However, this had no effect on the number and weight of piglets (Table 2). The intake of ground rapeseed diet was intermediate between the control and the rapeseed oil diet $(P>0 \cdot 05)$. Creep feed consump-

Table 2. Expt 1. Body weight and feed intake of sows and rearing results*

(Mean values for twelve sows and litters respectively per group with their pooled standard error)

\begin{tabular}{|c|c|c|c|c|}
\hline & Control & Rapeseed oil (40 g/kg diet) & Ground rapeseed (100 g/kg diet) & \\
\hline Glucosinolate content $(\mathrm{mmol} / \mathrm{kg}$ diet)... & $<0 \cdot 1$ & $<0 \cdot 1$ & 1.9 & SEM \\
\hline \multicolumn{5}{|l|}{ Body weight $(\mathrm{kg})$} \\
\hline 80th day of pregnancy & 226 & 225 & 221 & $7 \cdot 6$ \\
\hline 108th day of pregnancy & 243 & 240 & 235 & $8 \cdot 0$ \\
\hline Birth to $48 \mathrm{~h}$ post-partum & 224 & 223 & 218 & $7 \cdot 7$ \\
\hline End of experiment ( $28 \mathrm{~d}$ post-partum) & 204 & 214 & 203 & $7 \cdot 2$ \\
\hline \multicolumn{5}{|l|}{ Feed intake $(\mathrm{kg} / \mathrm{d}) \dagger$} \\
\hline Lactation (2-28 d post-partum) & $4 \cdot 12^{\mathrm{a}}$ & $4.83^{\mathrm{b}}$ & $4.41^{\mathrm{ab}}$ & 0.175 \\
\hline \multicolumn{5}{|l|}{ Piglets per litter $(n)$} \\
\hline Total born & $10 \cdot 4$ & $10 \cdot 9$ & $10 \cdot 2$ & 0.47 \\
\hline Alive at $24 \mathrm{~h}$ post-partum & $9 \cdot 3$ & $10 \cdot 2$ & $9 \cdot 3$ & 0.36 \\
\hline End of experiment ( $28 \mathrm{~d}$ post-partum) & $9 \cdot 0$ & $9 \cdot 1$ & 8.9 & 0.34 \\
\hline \multicolumn{5}{|l|}{ Body weight (kg per piglet) } \\
\hline At birth & 1.50 & 1.39 & 1.40 & 0.032 \\
\hline Alive at $24 \mathrm{~h}$ post-partum & 1.55 & 1.42 & 1.43 & 0.031 \\
\hline End of experiment ( $28 \mathrm{~d}$ post-partum) & $7 \cdot 24$ & $6 \cdot 91$ & 7.48 & 0.166 \\
\hline \multicolumn{5}{|l|}{ Litter weight $(\mathrm{kg})$} \\
\hline Total at birth & $15 \cdot 6$ & $15 \cdot 2$ & $14 \cdot 2$ & 0.73 \\
\hline Alive at $24 \mathrm{~h}$ post-partum & 14.4 & 14.5 & $13 \cdot 2$ & 0.72 \\
\hline End of experiment ( $28 \mathrm{~d}$ post-partum) & $65 \cdot 1$ & 62.9 & $66 \cdot 6$ & 3.38 \\
\hline
\end{tabular}

${ }_{\mathrm{a}, \mathrm{b}}$ Mean values within a row with unlike superscript letters were significantly different, $(P<0.05$, Newman-Keuls test).

* For details of diets and procedures, see Table 1 and p. 660 respectively.

† From 80th day of pregnancy to $1 \mathrm{~d}$ pre-partum: sows of the control group received $3.25 \mathrm{~kg}$ feed/d, sows of both the other groups received $3.00 \mathrm{~kg}$ feed/d. 
Table 3. Expt 2. Body weight and feed intake of sows and rearing results*

(Mean values for fifteen sows and litters respectively per group, with their pooled standard error)

\begin{tabular}{|c|c|c|c|c|}
\hline \multirow[b]{2}{*}{ Glucosinolate content (mmol/kg diet)... } & \multirow{2}{*}{$\frac{\text { Control }}{<0.1}$} & \multirow{2}{*}{$\frac{\text { Rapeseed press cake }(75 \mathrm{~g} / \mathrm{kg} \text { diet })}{2 \cdot 1}$} & \multirow{2}{*}{$\frac{\text { Rapeseed press cake }(150 \mathrm{~g} / \mathrm{kg} \text { diet })}{4 \cdot 2}$} & \multirow[b]{2}{*}{ SEM } \\
\hline & & & & \\
\hline \multicolumn{5}{|l|}{ Body weight (kg) } \\
\hline 86th day of pregnancy & 223 & 225 & 226 & $10 \cdot 6$ \\
\hline 110th day of pregnancy & 239 & 237 & 236 & $9 \cdot 9$ \\
\hline Birth to $48 \mathrm{~h}$ post-partum & 220 & 219 & 220 & $9 \cdot 6$ \\
\hline End of experiment ( $28 \mathrm{~d}$ post-partum) & 209 & 199 & 199 & $10 \cdot 1$ \\
\hline \multicolumn{5}{|l|}{ Feed intake $(\mathrm{kg} / \mathrm{d}) \dagger$} \\
\hline Lactation (2-28 d post-partum) & $4 \cdot 77^{\mathrm{a}}$ & $4 \cdot 34^{\mathrm{ab}}$ & $3.90^{\mathrm{b}}$ & 0.216 \\
\hline \multicolumn{5}{|l|}{ Animals per litter $(n)$} \\
\hline Total born & $11 \cdot 1$ & $11 \cdot 0$ & 10.5 & 0.63 \\
\hline Alive at $24 \mathrm{~h}$ post-partum & $9 \cdot 7$ & 9.5 & 8.7 & 0.41 \\
\hline End of experiment ( $28 \mathrm{~d}$ post-partum) & $9 \cdot 2^{\mathrm{a}}$ & $9 \cdot 0^{\mathrm{a}}$ & $7 \cdot 7^{\mathrm{b}}$ & 0.42 \\
\hline \multicolumn{5}{|l|}{ Body weight (kg per piglet) } \\
\hline At birth & 1.41 & 1.39 & 1.38 & 0.026 \\
\hline Alive from $24 \mathrm{~h}$ post-partum & 1.45 & 1.44 & 1.41 & 0.027 \\
\hline End of experiment ( $28 \mathrm{~d}$ post-partum) & 6.73 & $6 \cdot 67$ & 6.57 & 0.147 \\
\hline \multicolumn{5}{|l|}{ Litter weight (kg) } \\
\hline Total at birth & $14 \cdot 7$ & $15 \cdot 3$ & 14.5 & 0.80 \\
\hline Alive from $24 \mathrm{~h}$ post-partum & $14 \cdot 1$ & $13 \cdot 7$ & $12 \cdot 3$ & 0.67 \\
\hline End of experiment ( $28 \mathrm{~d}$ post-partum) & 61.9 & $60 \cdot 0$ & $50 \cdot 6$ & 3.65 \\
\hline
\end{tabular}

${ }^{\mathrm{a}, \mathrm{b}}$ Mean values within a row with unlike superscript letters were significantly different $(P<0.05$, Newman-Keuls test).

* For details of diets and procedures, see Table 1 and p. 660 respectively.

† From 86 th pregnancy day to $1 \mathrm{~d}$ pre-partum: $3.00 \mathrm{~kg}$ feed $/ \mathrm{d}$.

tion by piglets did not differ between groups: control $111 \mathrm{~g}$ creep feed/litter per d, rapeseed oil group $100 \mathrm{~g}$ creep feed/ litter per $\mathrm{d}$, rapeseed group $115 \mathrm{~g}$ creep feed/litter per $\mathrm{d}$.

In Expt 2 the inclusion of rapeseed press cake in sow diets reduced feed intake and rearing variables (Table 3). The decrease in sow feed intake and of the number of piglets weaned was significant in the group with the highest glucosinolate content in the feed $(150 \mathrm{~g}$ rapeseed press cake; $4.2 \mathrm{mmol}$ glucosinolates $/ \mathrm{kg}$ ). In the rapeseed-cake group the trend for a lower number of piglets per litter at birth continued during lactation with higher piglet losses. This gave a significantly reduced number of weaned piglets.

In this experiment feed consumption did not differ among groups of creep-fed piglets (control $103 \mathrm{~g}$ creep feed/litter per d, groups with 75 or $150 \mathrm{~g}$ rapeseed press cake/kg diet 99 or $95 \mathrm{~g}$ creep feed/litter per $\mathrm{d}$ ).

\section{Thyroid weight of stillborn piglets and those that died up to $24 h$ post partum}

In both experiments there was no effect of gestational feeding on the thyroid weight of piglets at birth: Expt 1, thyroid weight (mg/kg body weight): control 161 ( $n$ 14), rapeseed oil 137 ( $n$ 9), rapeseed 166 ( $n$ 11), (SEM 12.8); Expt 2, thyroid weight (mg/kg body weight): control 175 ( $n$ 21), 180 ( $n$ 22) and 189 ( $n$ 27) in the groups with 75 and $150 \mathrm{~g}$ rapeseed press cake/kg diet (SEM $\pm 10 \cdot 6)$.

\section{Thiocyanate status}

In the colostrum samples taken in both experiments $\mathrm{SCN}^{-}$ could not be detected $(<0.3 \mathrm{mg} / \mathrm{l})$. In Expt 1 rapeseed increased the $\mathrm{SCN}^{-}$concentration in sow serum, milk and piglet serum (Fig. 1). There was a pronounced concentration increase in the serum, which was directly related to glucosinolate intake in the rapeseed feed. The $\mathrm{SCN}^{-}$of milk and piglet serum responded weakly, but significantly, to glucosinolate in the mothers' diet.

In Expt 2 rapeseed press cake increased the $\mathrm{SCN}^{-}$ concentration, particularly in sow serum (Fig. 2). As in Expt 1 there was a small but significant response in $\mathrm{SCN}^{-}$ concentration in milk and piglet serum (Fig. 1).

There was no difference in $\mathrm{SCN}^{-}$status between groups with 75 or $150 \mathrm{~g}$ rapeseed press cake/kg diet (Fig. 2).

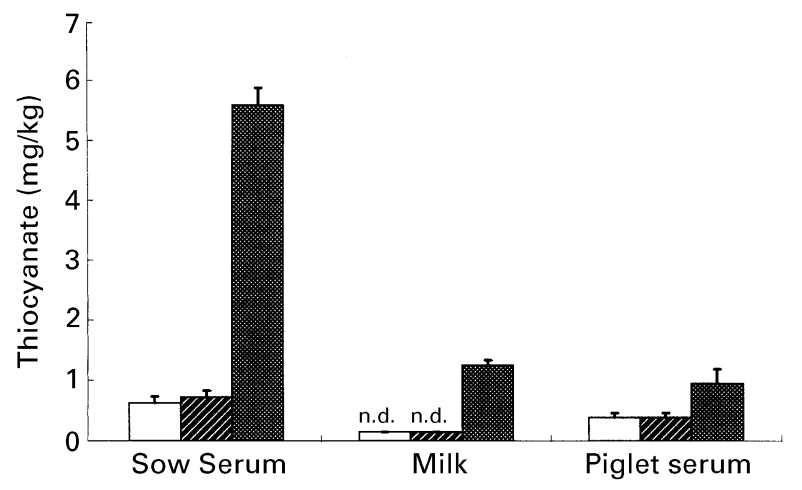

Fig. 1. Expt 1. The thiocyanate concentration of sow serum, milk and piglet serum at 27 days post-partum. For details of diets and procedures, see Table 1 and p. 660 respectively. $\square$, without rapeseed products; $\llbracket, 40 \mathrm{~g}$ rapeseed oil/kg diet; $100 \mathrm{~g}$ ground rapeseed $/ \mathrm{kg}$ diet. n.d., not detectable. Values are means for twelve sows and twenty-four piglets per group (two piglets per litter) with their standard errors represented by vertical bars. Mean values were significantly different between group with rapeseed $v$. both groups without dietary glucosinolates (the control and rapeseed oil group): $P<0.01$. The differences between the control and the rapeseed oil group were not significant. 


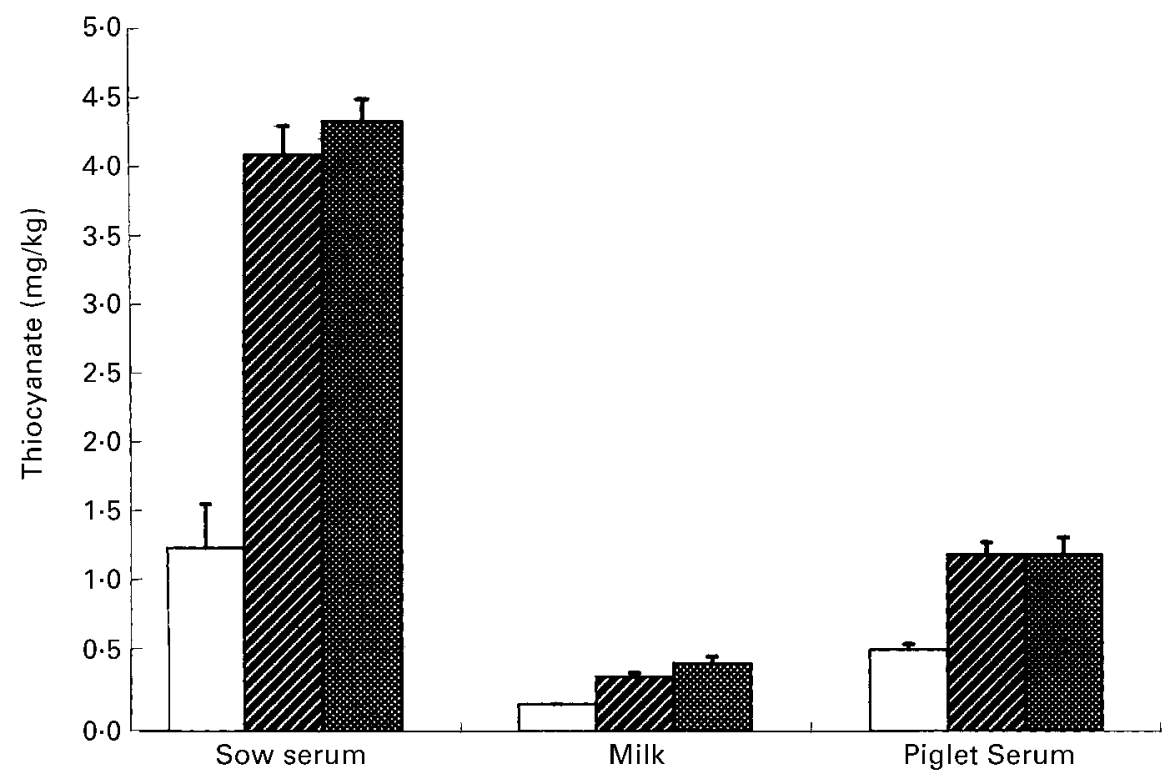

Fig. 2. Expt 2. The thiocyanate concentration of sow serum, milk and piglet serum at 27 days post-partum. For details of diets and procedures, see Table 1 and p. 660 respectively. $\square$, without rapeseed press cake; $\mathbb{Z}, 75 \mathrm{~g}$ rapeseed press cake/kg feed; $150 \mathrm{~g}$ rapeseed press cake/kg feed. Values are means for fifteen sows and thirty piglets per group (two piglets per litter) with their standard errors represented by vertical bars. Mean values were significantly different between groups with rapeseed press cake $v$. the control: $P<0.01$. There were no significant differences between the groups with 75 or $150 \mathrm{~g}$ rapeseed press cake/kg diet.

\section{Iodine and thyroid hormone status of sows and piglets}

In Expt 1 feeding ground rapeseed drastically lowered the colostrum I concentration from $134 \mu \mathrm{g} / \mathrm{l}$ in the control group and $110 \mu \mathrm{g} / \mathrm{l}$ in the rapeseed-oil group to $55 \mu \mathrm{g} / \mathrm{l}$ colostrum in the group on the glucosinolate diet (SEM 11.4, minimum significant difference 33).

Rapeseed press cake (Expt 2) also significantly diminished colostrum I concentration. The control sows had $170 \mu \mathrm{g} \mathrm{I} /$ litre. In the groups with 75 and $150 \mathrm{~g}$ rapeseed press cake/ $\mathrm{kg}$ feed there was $127 \mu \mathrm{g} \mathrm{I} /$ litre and $87 \mu \mathrm{g} \mathrm{I} /$ litre in the colostrum (SEM 16.3, minimum significant difference 46).

In Expt 1 there was a significant effect of I administration to sows on their serum I concentration (Table 4). The statistical comparison was significant only for the difference between the groups without I and with $300 \mu \mathrm{g}$ supplementary $\mathrm{I} / \mathrm{kg}$ rapeseed diet (minimum significant difference $14 \mu \mathrm{g} \mathrm{I} /$ litre serum).

Table 4. Expt 1. Response of serum iodine and thyroid hormone concentrations and milk iodine concentration to rapeseed and rapeseed oil and iodine supplementation in the sow diet*

(Mean values for four sows and two piglets per litter (eight piglets per group) with their pooled standard error)

\begin{tabular}{|c|c|c|c|c|c|c|c|c|c|c|}
\hline \multirow[b]{2}{*}{$\begin{array}{l}\text { Glucosinolate content }(\mathrm{mmol} / \mathrm{kg} \text { diet }) \ldots \\
\text { lodine dosage }(\mu \mathrm{g} / \mathrm{kg} \text { diet }) \ldots\end{array}$} & \multicolumn{3}{|c|}{ Control (without rapeseed feed) } & \multicolumn{3}{|c|}{ Rapeseed oil (40 g/kg diet) } & \multicolumn{4}{|c|}{ Ground rapeseed (100 g/kg diet) } \\
\hline & 0 & $\begin{array}{l}<0 \cdot 1 \\
150\end{array}$ & 300 & 0 & $\begin{array}{l}<0 \cdot 1 \\
150\end{array}$ & 300 & 0 & $\begin{array}{l}1.9 \\
150\end{array}$ & 300 & SEM \\
\hline \multicolumn{11}{|l|}{ lodine $(\mu \mathrm{g} / \mathrm{I})$} \\
\hline Sow serum $\ddagger \S$ & $27^{\mathrm{abc}}$ & $39^{\mathrm{bc}}$ & $26^{\mathrm{ab}}$ & $23^{a}$ & $27^{\mathrm{abc}}$ & $33^{a b c}$ & $24^{a}$ & $34^{a b c}$ & $41^{\mathrm{c}}$ & 3.4 \\
\hline Milk $\ddagger \S$ & $54^{\mathrm{ab}}$ & $136^{\mathrm{bc}}$ & $161^{\mathrm{c}}$ & $88^{a b c}$ & $95^{a b c}$ & $150^{c}$ & $42^{a}$ & $66^{\mathrm{ab}}$ & $69^{\mathrm{ab}}$ & $21 \cdot 1$ \\
\hline Piglet serum $\ddagger \S$ & $48^{\mathrm{cd}}$ & $49^{\mathrm{cd}}$ & $59^{e}$ & $45^{\mathrm{bc}}$ & $50^{\mathrm{cd}}$ & $54^{\text {de }}$ & $36^{a}$ & $38^{\mathrm{ab}}$ & $47^{\mathrm{cd}}$ & 2.9 \\
\hline \multicolumn{11}{|l|}{$\mathrm{T}_{4}(\mathrm{nmol} / \mathrm{l})$} \\
\hline Sow serum & 26 & 32 & 16 & 20 & 22 & 23 & 23 & 20 & 29 & 3.8 \\
\hline Piglet serum $\ddagger$ & $80^{\mathrm{ab}}$ & $75^{\mathrm{ab}}$ & $74^{\mathrm{ab}}$ & $62^{\mathrm{a}}$ & $90^{\mathrm{b}}$ & $79^{a b}$ & $59^{a}$ & $75^{\mathrm{ab}}$ & $81^{\mathrm{ab}}$ & 5.5 \\
\hline \multicolumn{11}{|l|}{$\mathrm{T}_{3}(\mathrm{nmol} / \mathrm{l})$} \\
\hline Sow serum & 0.8 & $1 \cdot 1$ & 0.6 & 0.9 & 0.8 & $0 \cdot 8$ & 0.8 & 0.6 & $0 \cdot 8$ & 0.09 \\
\hline Piglet serum & 1.8 & 1.4 & 1.5 & 1.3 & 1.3 & 1.5 & $1 \cdot 3$ & 1.6 & 1.6 & 0.14 \\
\hline \multicolumn{11}{|c|}{ lodine bound in $T_{4}+T_{3}$ related to serum iodine concentration (\%) } \\
\hline Sow serum $\ddagger$ & 50 & 43 & 32 & 46 & 43 & 36 & 50 & 31 & 37 & $6 \cdot 6$ \\
\hline Piglet serum $\ddagger \S$ & $86^{a b c}$ & $79^{a b}$ & $65^{a}$ & $71^{\mathrm{ab}}$ & $92^{\mathrm{bc}}$ & $75^{a b}$ & $85^{a b c}$ & $102^{\mathrm{c}}$ & $89^{b c}$ & $5 \cdot 7$ \\
\hline
\end{tabular}

$\mathrm{T}_{4}$, thyroxine; $\mathrm{T}_{3}$, triiodothyronine.

$\mathrm{a}, \mathrm{b}, \mathrm{c}, \mathrm{d}, \mathrm{e}$ Mean values within a row with unlike superscript letters were significantly different $(P<0.05$, Newman-Keuls test)

* For details of diets and procedures, see Table 1 and p. 660 respectively.

$\dagger$ Significant effects of glucosinolates by two-way ANOVA $(P<0.05)$

$¥$ Significant effects of iodine by two-way ANOVA $(P<0.05)$.

$\S$ Significant glucosinolates $\times$ iodine interaction by two-way ANOVA $(P<0.05)$. 
Table 5. Expt 2. Response of serum iodine and thyroid hormone concentrations and milk iodine concentrations to graded levels of rapeseed press cake and iodine supplementation in the sow diet ${ }^{\star}$

(Mean values for five sows and two piglets per litter (ten piglets per group) with their pooled standard derivation)

\begin{tabular}{|c|c|c|c|c|c|c|c|c|c|c|}
\hline \multirow{3}{*}{$\begin{array}{l}\text { Glucosinolate content }(\mathrm{mmol} / \mathrm{kg} \text { diet }) \ldots \\
\text { lodine dosage }(\mu \mathrm{g} / \mathrm{kg} \text { diet)... }\end{array}$} & \multicolumn{3}{|c|}{$\begin{array}{l}\text { Control } \\
\text { (without rapeseed feed) }\end{array}$} & \multicolumn{3}{|c|}{$\begin{array}{l}\text { Rapeseed press cake } \\
\text { (75 g/kg diet) }\end{array}$} & \multicolumn{4}{|c|}{$\begin{array}{l}\text { Rapeseed press cake } \\
\text { (150 g/kg diet })\end{array}$} \\
\hline & & $<0.1$ & & & $2 \cdot 1$ & & & $4 \cdot 2$ & & \\
\hline & 150 & 300 & 600 & 150 & 300 & 600 & 150 & 300 & 600 & SEM \\
\hline \multicolumn{11}{|l|}{ lodine $(\mu \mathrm{g} / \mathrm{l})$} \\
\hline Sow serumt & 22 & 21 & 28 & 35 & 31 & 29 & 33 & 31 & 39 & $3 \cdot 4$ \\
\hline Milk†‡ & $73^{a}$ & $65^{a}$ & $168^{\mathrm{b}}$ & $53^{a}$ & $53^{a}$ & $75^{\mathrm{a}}$ & $44^{\mathrm{a}}$ & $38^{\mathrm{a}}$ & $89^{\mathrm{a}}$ & $21 \cdot 7$ \\
\hline Piglet serum†‡ & $64^{\mathrm{bc}}$ & $58^{a b c}$ & $72^{c}$ & $51^{\mathrm{ab}}$ & $58^{a b c}$ & $63^{\mathrm{bc}}$ & $49^{\mathrm{ab}}$ & $45^{a}$ & $68^{c}$ & 4.2 \\
\hline \multicolumn{11}{|l|}{$\mathrm{T}_{4}(\mathrm{nmol} / \mathrm{l})$} \\
\hline Sow serum & $32^{\mathrm{abc}}$ & $22^{\mathrm{ab}}$ & $20^{\mathrm{a}}$ & $29^{a b c}$ & $35^{\mathrm{bc}}$ & $29^{a b c}$ & $38^{\mathrm{c}}$ & $37^{\mathrm{c}}$ & $38^{c}$ & 3.7 \\
\hline Piglet serum $\ddagger$ & $94^{\text {bcd }}$ & $82^{a b}$ & $85^{a b c}$ & $79^{a}$ & $74^{\mathrm{a}}$ & $102^{d}$ & $78^{\mathrm{a}}$ & $75^{a}$ & $98^{\mathrm{cd}}$ & $7 \cdot 1$ \\
\hline \multicolumn{11}{|l|}{$\mathrm{T}_{3}(\mathrm{nmol} / \mathrm{l})$} \\
\hline Sow serum $†$ & $2 \cdot 0$ & 1.4 & 1.5 & $2 \cdot 1$ & 2.4 & 2.5 & $2 \cdot 8$ & $2 \cdot 7$ & $2 \cdot 3$ & 0.39 \\
\hline Piglet serum & $3 \cdot 7$ & $3 \cdot 1$ & $3 \cdot 0$ & $2 \cdot 9$ & 2.5 & $3 \cdot 0$ & $3 \cdot 1$ & $3 \cdot 0$ & $3 \cdot 2$ & 0.34 \\
\hline \multicolumn{11}{|c|}{ lodine bound in $\mathrm{T}_{4}+\mathrm{T}_{3}$ related to serum iodine concentration (\%) } \\
\hline Sow serum $\ddagger$ & $77^{\mathrm{b}}$ & $56^{\mathrm{ab}}$ & $38^{\mathrm{a}}$ & $44^{\mathrm{ab}}$ & $60^{\mathrm{ab}}$ & $54^{\mathrm{ab}}$ & $62^{\mathrm{ab}}$ & $64^{\mathrm{ab}}$ & $52^{\mathrm{ab}}$ & $6 \cdot 4$ \\
\hline Piglet serum & 77 & 74 & 62 & 81 & 67 & 84 & 84 & 88 & 76 & $5 \cdot 8$ \\
\hline
\end{tabular}

$\mathrm{T}_{4}$, thyroxine; $\mathrm{T}_{3}$, triiodothyronine.

$\mathrm{a,b,c,d, \textrm {e }}$ Mean values within a row with unlike superscript letters were significantly different $(P<0.05$, Newman-Keuls test).

* For details of diets and procedures, see Table 1 and p. 660 respectively.

$\dagger$ Significant effects of glucosinolates by two-way ANOVA $(P<0.05)$.

¥ Significant effects of iodine by two-way ANOVA $(P<0.05)$.

Mature milk I concentration responded to rapeseed and to diet I. It increased to $>150 \mu \mathrm{g}$ I/litre milk in response to $300 \mu \mathrm{g}$ supplementary $\mathrm{I} / \mathrm{kg}$ in the glucosinolate-free diet. However, this level of I supplementation of the rapeseed diet could not bring the milk I level to half this concentration.

In piglets both the I and the glucosinolates in the sow diets significantly affected serum I concentration. It increased with I administration to the sows and decreased with rapeseed feeding. Piglets from mothers without added I and those with $150 \mu \mathrm{g}$ supplementary I/kg diet had almost the same serum I concentration. Only the highest I dose fed to the sows $(300 \mu \mathrm{g} / \mathrm{kg}$ diet) gave a significant increase in piglet serum I concentration.

In Expt $1, \mathrm{~T}_{4}$ and $\mathrm{T}_{3}$ serum concentration of sows was not affected by glucosinolates or by dietary I. In piglets the serum $\mathrm{T}_{4}$ concentration responded to maternal I supply. The piglets from sows fed the ground rapeseed diet or the rapeseed-oil diet without supplementary I had the lowest serum $\mathrm{T}_{4}$ concentration.

In sow serum the $I$ represented by $T_{4}$ and $T_{3}$ was decreased from about one-half of groups without $\mathrm{I}$ supplementation to one-third in groups with I supply, which was a significant I effect $(P<0 \cdot 05)$. Summarising the groups without I and with 150 or $300 \mu \mathrm{g}$ supplementary $\mathrm{I} / \mathrm{kg}$ sow diet gave $49 \%, 39 \%$ and $35 \%$ (SEM 3.8), hormone bound as a percentage of total serum I with a minimum significant difference of $13 \%$. In piglet serum there were significant effects of glucosinolates and I in the mothers' diet in relation to thyroid hormone I to (total) serum I. Piglets from sows fed rapeseed with I had a significantly higher percentage of I as hormone I than piglets from sows fed the same I dosage and a control diet free of glucosinolates. Piglets from sows on diets without glucosinolates tended, with increasing I dosage, to have a decreased hormone I:total serum I ratio. Compared with their mothers, piglets had a significantly higher hormone I:total serum I ratio. This was caused by a doubled thyroid hormone concentration and by a $50 \%$ higher serum I concentration in the young animals.

In Expt 2, the sow serum I concentration was not affected by dietary I (Table 5). However, rapeseed cake feeding gave a significantly higher I concentration in sow serum than in the glucosinolate-free control group. As in Expt 1 (Table 4), in Expt 2 (Table 5), milk and piglet serum I concentration increased with increased I dosage in sow diets and it was reduced by feeding rape.

The $T_{4}$ and the $T_{3}$ concentration of sow serum were significantly higher with rapeseed-press cake feeding, particularly at the highest dietary level tested. The significant glucosinolate effect on the $\mathrm{T}_{3}$ status by ANOVA could not be confirmed by the Newman-Keuls test. Summarising the three I dosage groups for each level of dietary rapeseed press cake, including the control, not fed rapeseed press cake, the differences between the control and the sows which received $175 \mathrm{~g}$ rapeseed press cake/kg diet were significant (fifteen sows per group, $\mathrm{T}_{3}(\mathrm{nmol} / \mathrm{l}$ serum): $1.6,2.3$ and 2.8 (SEM 0.23), minimum significant difference $0 \cdot 8$ ).

There was an effect of I dosage in sow diets on the $\mathrm{T}_{4}$ concentration of piglet serum. The $T_{4}+T_{3} I$ as a part of sow serum total I concentration decreased with increased I in the diet in the absence of rapeseed press cake. With press cake feeding there was no effect of glucosinolates or I on the hormone I fraction of the total serum I. In piglet serum there was no nutritional effect on serum I distribution. As in Expt 1 (Table 4), in Expt 2 (Table 5) more piglet serum I was represented by $T_{4}+T_{3}$ than of the mothers' serum I.

Spot urine and faeces samples taken from sows fed $150 \mathrm{~g}$ rapeseed press cake/kg diet had a significantly higher I concentration than the controls without glucosinolates in their diet $(P<0.05$, Table 6). Relating urine $\mathrm{I}$ to the 
Table 6. Expt 2. Groups without rapeseed-press cake feeding and with $150 \mathrm{~g}$ rapeseed press cake/kg sow diet: concentration of iodine in spot urine samples and in faeces samples from lactation day 26

(Mean values for five sows per group, with their pooled standard error)

\begin{tabular}{|c|c|c|c|c|c|c|c|c|}
\hline \multirow[b]{2}{*}{$\begin{array}{l}\text { Glucosinolate content }(\mathrm{mmol} / \mathrm{kg} \text { diet }) \ldots \\
\text { lodine dosage }(\mu \mathrm{g} / \mathrm{kg} \text { diet }) \ldots\end{array}$} & & \multicolumn{3}{|c|}{ Control without rapeseed feed } & \multicolumn{4}{|c|}{ Rapeseed press cake $150 \mathrm{~g} / \mathrm{kg}$ diet } \\
\hline & & 150 & $\begin{array}{l}<0 \cdot 1 \\
300\end{array}$ & 600 & 150 & $\begin{array}{l}4 \cdot 2 \\
300\end{array}$ & 600 & SEM \\
\hline \multicolumn{9}{|l|}{ lodine } \\
\hline \multirow[t]{2}{*}{ Sow urine } & $(\mu \mathrm{g} / \mathrm{l}) \dagger$ & $141^{a}$ & $181^{\mathrm{a}}$ & $208^{a b}$ & $373^{\mathrm{bc}}$ & $379^{\mathrm{bc}}$ & $453^{\mathrm{c}}$ & $57 \cdot 0$ \\
\hline & ( $\mu \mathrm{g} / \mathrm{g}$ creatinine $) \dagger$ & 198 & 234 & 246 & 206 & 459 & 620 & $107 \cdot 5$ \\
\hline \multirow[t]{2}{*}{ Sow faeces } & ( $\mu \mathrm{g} / \mathrm{kg}$ fresh matter) $\dagger$ & 132 & 128 & 159 & 216 & 204 & 240 & 25.4 \\
\hline & $(\mu \mathrm{g} / \mathrm{kg} \mathrm{DM}) \dagger$ & 440 & 465 & 508 & 617 & 656 & 721 & 68.1 \\
\hline
\end{tabular}

a,b,c Mean values within a row with unlike superscript letters were significantly different $(P<0.05$, Newman-Keuls test).

${ }^{\star}$ For details of diets and procedures, see Table 1 and p. 660 respectively.

† Significant effects of glucosinolates by two-way ANOVA $(P<0.05)$.

creatinine concentration did not change the result of an increased I loss on a rapeseed-press cake diet. A low $\mathrm{I}$ :creatinine ratio in the urine from sows of the rapeseedcake group without supplementary I was caused by a high creatinine concentration $(1.9 \mathrm{~g} / 1$ urine $v .0 .8$ and 1.3 in the other groups (SEM 0.28) $\mathrm{g} / \mathrm{l}, P>0 \cdot 05$ ). No significance of dietary I on the I concentration of excreta could be detected. There was only a trend towards a higher I:creatinine ratio $(P=0 \cdot 12)$ with increased dietary I.

\section{Discussion}

Glucosinolates of rapeseed products and rearing variables in sow experiments

A glucosinolate concentration of $35 \mathrm{mmol} / \mathrm{kg}$ defatted rapeseed or rapeseed press cake (basis $910 \mathrm{~g}$ defatted $\mathrm{DM} / \mathrm{kg}$ ) represented the upper third of the 420 samples of rapeseed investigated from batches harvested in Thuringia Jena, Germany, from 1992 to 1998. The concentration of the batches was below the European Community (1999) maximum glucosinolate levels of ' 00 ' rapeseed $(25 \mathrm{mmol}$ glucosinolates $/ \mathrm{kg}$ seed is equivalent to $40 \mathrm{mmol} / \mathrm{kg}$ defatted rapeseed on the basis of $910 \mathrm{~g} \mathrm{DM} / \mathrm{kg}$ ). However, this official European Community (1999) borderline value is restricted to seed certified for sowing. In harvested rapeseed and its products it is not obligatory to determine the glucosinolate concentration. Improving the position of rapeseed as a feed requires control of the glucosinolate concentration from the field to the oil mill to the feed compounder. Furthermore, a 'safe-use' concentration must be defined. Fenwick (1984) recommended $30 \mathrm{mmol} / \mathrm{kg}$ defatted matter. Recent proposals for an acceptable glucosinolate concentration of rapeseed in feed are much lower (Campbell et al. 1999).

Grinding or pressing of rapeseed did not change the glucosinolate content on a fat-free basis (Schöne et al. 1997c). Degradation products of glucosinolates were not detected in ground rapeseed or press cake. Probably no, or only minor, glucosinolate hydrolysis was caused in the dry feed by minor myrosinase activity. Addition of water to ground rapeseed or rapeseed press cake gave almost total glucosinolate degradation (Schöne et al. 1997c).

Contrasting with the results reviewed by Drochner
(1989) in both these experiments there was no benefit of fat application via rapeseed, the oil or the press cake on sow-milk fat content and piglet performance (Schöne et al. 1998a).

In Expt 2 the depression in feed intake and rearing results at the $150 \mathrm{~g} / \mathrm{kg}$ diet rapeseed-press cake level may have resulted from a high glucosinolate concentration (4.2 $\mathrm{mmol} / \mathrm{kg}$ diet). Etienne \& Dourmad (1994) tested up to $7.4 \mathrm{mmol}$ glucosinolates $/ \mathrm{kg}$ rapeseed-meal diets during gestation. This resulted in a significant weight loss of fetuses removed at pregnancy day 111. Fetus number and the ovulation rate and embryonic mortality were not affected in this experiment.

In a previous sow experiment (Schöne et al. 1997b), $250 \mathrm{~g}$ rapeseed meal (10 mmol glucosinolates) $/ \mathrm{kg}$ diet decreased piglet number per litter and litter weight by $8 \%$ at weaning after 28 d lactation (100\% represents control, without glucosinolates), which agrees with the findings of the present Expt 2. However, in the previous experiment (Schöne et al. 1997b) the sows consumed the high-rapeseed meal diet to a surprisingly great extent, which did not differ from the intake of the control group fed a rapeseed-free and glucosinolate-free ration.

In contrast with the short-term and limited number of sow experiments, there are many more rapeseed-feed experiments with growing and fattening pigs. According to these dose-response experiments, pigs tolerated rapeseed-feed diets between 1.4 and 2.4 mmol glucosinolates/ $\mathrm{kg}$ diet without feed intake depression (Nürnberg et al. 1994; Schöne et al. 1997a,c; Tischendorf et al. 1998). In agreement with these findings on fattening pigs and in agreement with the results of the few sow experiments that have been conducted, at present a breeding sow can be given up to $2 \mathrm{mmol}$ glucosinolates $/ \mathrm{kg}$ diet via rapeseed feed.

\section{Thiocyanate, iodine and thyroid hormone status of sows and their piglets}

In accordance with findings from earlier experiments with feeding of rapeseed meal to different animal species (Paik et al. 1980; Schöne et al. 1990) as well as with rapeseed and rapeseed press cake fed to dairy cows (Jahreis et al. 1995 ) or to growing pigs (Schöne et al. 1997c), both the 
rapeseed feeds in the present experiments drastically increased serum $\mathrm{SCN}^{-}$concentration in sows. The nonreproducible dose response to dietary glucosinolate concentration of thiocyanate serum concentration in sows (Expt 1, Expt 2, Figs. 1 and 2) is in agreement with results from previous experiments with growing pigs (Schöne et al. $1997 c$ ). It is presumably the result of rapid renal $\mathrm{SCN}^{-}$ elimination. In balance experiments the urine $\mathrm{SCN}^{-}$ correlated with rapeseed-feed quantities and the KSCN administered (Schöne \& Paetzelt, 1987).

There was only a low $\mathrm{SCN}^{-}$concentration in sow milk and piglet serum. Due to the glucosinolates in the sow diets the $\mathrm{SCN}^{-}$concentration increase was significant $(P<$ 0.01), but these traces of a non-toxic compound (Schöne \& Paetzelt, 1987) seem to have no consequences on piglets.

Contrary to Expt 1 a significant effect of dietary I dosage on the I concentration of sow serum was not found in the previous sow experiment including also sow groups without supplementary I (Schöne et al. 1997b). The $\mathrm{T}_{4}$ serum concentration representing a great part of serum I concentration was not affected by the diet I in both these experiments. (The glucosinolate effect on serum $\mathrm{I}$ and $\mathrm{T}_{4}$ will be discussed later.) In the thyroid the extent and I content of thyroglobulin, a prerequisite for $\mathrm{T}_{4}$ production, might be higher in older animals and this might guarantee a serum $\mathrm{T}_{4}$ concentration which is unaffected by low I consumption.

A concentration from 42 to $168 \mu \mathrm{g} / \mathrm{l}$ milk as the lowest and highest mean value in both the present experiments represented a milk I concentration recorded for human subjects (Tiran et al. 1993) and the cow (Groppel, 1986; Jahreis et al. 1995). In the cited investigations I was not determined by ion-sensitive electrodes.

In the sow experiment, carried out in 1989, diets without supplementary I had only $14 \mu \mathrm{g}$ I/litre in milk. In the reproduction cycle and gestation period before the start of this experiment, the I supply was low (about $150 \mu \mathrm{g}$ additional $\mathrm{I} / \mathrm{kg}$ feed) representing the recommendations in the former German Democratic Republic (Röhnisch et al. 1987). Before the beginning of the present experiments, the I supply was higher. A seven-fold I dosage (1000 $\mu \mathrm{g}$ additional $\mathrm{I} / \mathrm{kg}$ diet) was given, which is above the recommendations of the animal nutrition societies (Agricultural Council, 1981; Gesellschaft für Ernährungsphysiologie, 1987; National Research Council, 1998). However, this represents a moderate level with regard to the sow feed dosage (up to $3500 \mu \mathrm{g} \mathrm{I} / \mathrm{kg}$ sow feed) currently applied by German feed compounders. It can therefore be assumed that the higher I supply during pregnancy increased the thyroid I depot, resulting presumably in higher I release by the gland and a higher milk I concentration.

With regard to the lack of a difference in milk I concentration of the sow groups with 150 or $300 \mu \mathrm{g}$ of supplementary I/kg diet in each experiment (Tables 4 and 5 ), the higher dosage seemed to give a higher percentage in the thyroid I depot that could be less mobilised. Iodide uptake by sodium iodide symporter has been demonstrated not only in the thyroid, but also in various extrathyroidal tissues including the mammary gland (Spitzweg et al. 1998). In the flow of iodide from intestinal absorption, flow to the thyroid seems to occur prior to a flow to the mammary glands. This is probably due to a higher thyroid iodide symporter content (Ajjan et al. 1998).

The serum I concentration of the piglets reflected changes in milk I concentration with regard to sow $\times$ diets effects. Contrasting with the favourable I status of the adults, young animals have smaller depots and higher dietary requirements in their intensively growing tissues. These higher tissue needs of piglets might be reflected by I and $\mathrm{T}_{4}$ serum levels which were significantly higher than the serum concentrations of their mothers. A higher percentage of hormone I in the total serum I concentration in piglets compared with the sows may also result from the anabolic state characterising the young organism.

Further, I dosage affects the percentage of hormone I. A high I intake increases the iodide fraction of the serum derived almost completely from I absorption. The levels of $\mathrm{T}_{4}$ and $\mathrm{T}_{3}$ remain unaffected from $\mathrm{I}$ intake in a broad range and the percentage of total serum I drops with increasing serum iodide. In the adult a low thyroid hormone percentage is the rule because the low serum and presumably equally low tissue thyroid hormone concentration is probably exceeded by the iodide part of serum.

Confirming a depression in milk I with similar changes in serum $\mathrm{I}$ and $\mathrm{T}_{4}$ status of piglets by glucosinolates in both the present experiments with rapeseed and rapeseed press cake and in a former rapeseed-meal experiment (Schöne et al. $1997 b$ ), there were no glucosinolate effects on sow serum I or thyroid hormone concentration in either the present Expt 1 or the former rapeseed-meal experiment. However, in Expt 2, the sows had a glucosinolate-induced increase of I and thyroid hormone concentration of serum (Table 5) with a simultaneous decrease in milk I concentration.

In the former experiments, fattening pigs reacted to short-term feeding of treated rapeseed meal with enough I (0.6 mmol glucosinolates $/ \mathrm{kg}$ diet) with increased serum $\mathrm{T}_{4}$ concentrations (Schöne et al. 1990). More glucosinolates, $10 \mathrm{mmol} / \mathrm{kg}$ diet, or prolonged exposure had no effects on, or depressed, serum $\mathrm{T}_{4}$ concentration.

For serum $I$, the increase in $T_{4}$ and sometimes $T_{3}$ concentration due to short-term glucosinolate exposure in the case of an I-filled thyroid depot has to be considered as being caused by: (1) a changed hormone turnover and hormone requirement of tissues; (2) a higher thyroid activity respectively.

According to (1), glucosinolate degradation products, i.e. isothiocyanates, nitriles and oxazolidinethiones inhibiting liver and other intensively regenerating tissues are counteracted by more $\mathrm{T}_{3}$ (Spiegel et al. 1993). This sustains or increases blood serum concentration of the precursor $\mathrm{T}_{4}$ releasing the $\mathrm{T}_{3}$ by microsomal 5-deiodase action.

The more active thyroid, according to (2), liberates more hormone sustaining a high serum $\mathrm{T}_{4}$ concentration. The hyperplasia and hypertrophy of thyroid epithelia implies increased peroxidase activity (Taurog, 1985) shifting from oxidation of iodide to that of oxazolidinethiones and additionally consuming the thyroglobulin I. There seem to be similarities in the iodide uptake by the thyroid and mammary epithelial cells. Both cell types possess an iodide symporter (Rillema \& Rowady, 1997) and both these provide peroxidase activity. Similar effects of rapeseedfeed compounds on mammary gland peroxidase action as 
on thyroid enzyme may create more iodide causing low I concentrations in the milk as well as in the thyroid.

There will be a relative surplus of iodide caused by peroxidases, which are unable to simultaneously oxidise the glucosinolate degradation products and iodide. From this it follows that the animal will excrete more iodide as was shown with significantly higher I concentrations measured in urine samples from sows which consumed the rapeseed press cake $(P<0 \cdot 05$, Table 6$)$. In this experiment not only the urine but the faeces of sows consuming the rapeseedpress cake diet had a significantly higher I concentration than sows consuming a glucosinolate-free diet. In contrast to urine I, which is almost totally in the form of iodide, a lot of faeces I is represented by intact thyroid hormones that escaped reabsorption in the intestine (Di Stefano \& Sapin, 1987).

\section{Estimated sow iodine requirement}

I intake and loss was estimated (Fig. 3) despite some uncertainty of the I concentration in one milk, urine and faeces sample and the milk yield or urine excretion, e.g. 20-80 ml urine/kg body weight per d (Kraft \& Dürr, 1996). However, some conclusions can be drawn, taking into account similar error conditions at sampling in all sow groups.

At low I dosages, milk I output seems not to be related to the low intake level. This has already been explained by different thyroid I uptake and release. Only the highest dose of I tested $(600 \mu \mathrm{g} \mathrm{I} / \mathrm{kg}$ diet) gave a milk-I response. A daily intake difference of $1500 \mu \mathrm{g}$ I between both I-dosage groups responding to an I dose of $300 v .600 \mu \mathrm{g} \mathrm{I} / \mathrm{kg}$ diet led to an additional $700 \mu \mathrm{g}$ I in daily milk output indicating about a $45 \%$ utilisation rate (Fig. 3).

In Expt 1, there was a $41 \%$ I utilisation and in a further experiment with a higher dose, $1000 \mu \mathrm{g} / \mathrm{kg}$ diet (Schöne et al. 1997b) an $18 \%$ utilisation was calculated. Extremely low or high dietary I dosages lower I utilisation. In the case of a low I intake, a high renal and faecal I excretion results from large thyroid depots in older animals. An I excess from high I administration will rapidly be eliminated by increasing the urine I concentration. Glucosinolates also lower I utilisation. In the rapeseed-press cake group (Fig. 3), milk contained $26 \%$ I in relation to intake. In the previous rapeseed-meal experiment, a much higher dietary glucosinolate content gave an extremely low I utilisation of about $1 \%$ milk I as a percentage of dietary I intake.

The 18-45 \% sows' milk I of controls in our experiments related to dietary $I$ intake are in the range of rat experiments results with radioactive I (reviewed by Miller et al. 1974) which found 15-50\% administered $\mathrm{I}$ in the milk.

A daily I intake increasing from 700 to 1400 to $2900 \mu \mathrm{g}$ would increase the sum of urinary (Fig. 3) and faecal I from 1600 to 1900 and $2200 \mu \mathrm{g}$ indicating dominant thyroid I release at lower I dosages and dominant thyroid I uptake at higher I dosages. There is a shift from intestinal to renal excretion giving more I because inevitable faecal I loss consisting of thyroid hormones and their degradation products will decrease.

Estimating an I requirement for the lactating sow of
(A)

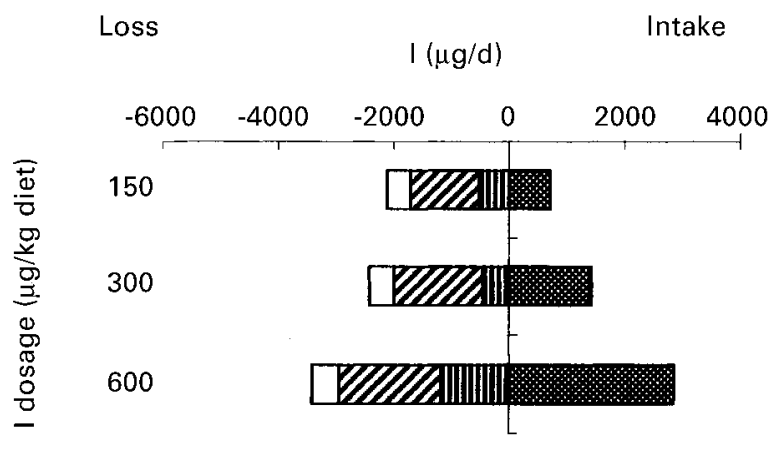

(B)

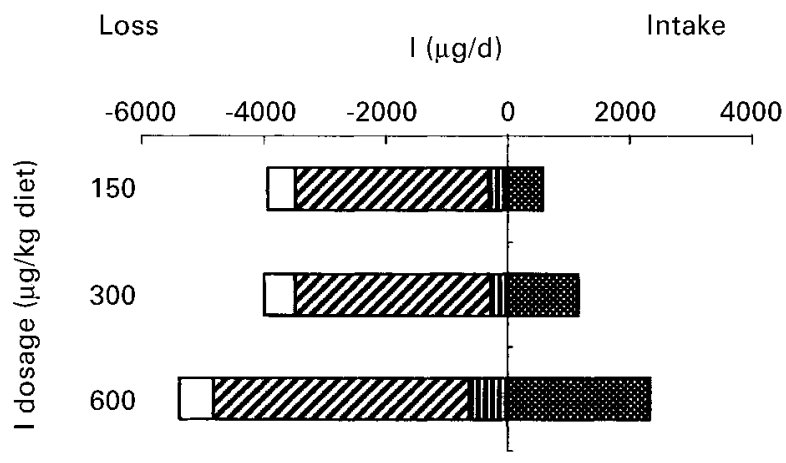

Fig. 3. lodine intake and iodine loss in milk, urine and faeces. (A), control (without rapeseed feed), $<0.1 \mathrm{mmol}$ glucosinolates $/ \mathrm{kg}$ diet; (B), $150 \mathrm{~g}$ rapeseed press cake/ $\mathrm{kg}$ diet, $4.2 \mathrm{mmol}$ glucosinolates $/ \mathrm{kg}$ diet. For details of diets and procedures, see Table 1 and p. 660

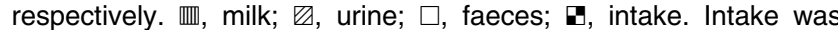
calculated from measured feed intake multiplied by iodine dosage, and milk iodine results from an estimated $7 \mathrm{~kg}$ milk yield multiplied by the measured milk iodine concentration (Table 5). Faecal iodine excretion was estimated as $20 \%$ feed DM intake multiplied by the iodine concentration and the DM concentration in the faeces samples (Table 6). Urine excretion was estimated to be $8.5 \mathrm{~kg}$ (40 ml/kg sow body mass).

$600 \mu \mathrm{g}$ supplementary $\mathrm{I} / \mathrm{kg}$ of a grain soyabean-meal diet seems to guarantee: (1) a reasonable milk I concentration significantly above $100 \mu \mathrm{g} / \mathrm{kg}$; (2) an almost balanced intake and loss of $\mathrm{I}$. This recommendation is derived from the findings in these present experiments and is in the range of cited current UK and German recommendations (Agricultural Council, 1981; Gesellschaft für Ernährungsphysiologie, 1987). However, it is significantly higher than the National Research Council (1998) recommendations. The addition of $600 \mu \mathrm{g} \mathrm{I} / \mathrm{kg}$ to a rapeseed-press cake diet containing $4.2 \mathrm{mmol}$ glucosinolates $/ \mathrm{kg}$ led to I loss being more than double I intake. Therefore, even small quantities of rapeseed feed and glucosinolate seem to require I addition of $>1000 \mu \mathrm{g} / \mathrm{kg}$ diet, i.e. about double the current UK and German recommendations.

In the present work $150 \mathrm{~g} / \mathrm{kg}$ rapeseed-press cake $(4.2 \mathrm{mmol}$ glucosinolates $/ \mathrm{kg}$ feed $)$ diminished the feed 
intake of lactating sows and the number of piglets reared. However, $75 \mathrm{~g} / \mathrm{kg}$ rapeseed press cake $(2.1 \mathrm{mmol}$ glucosinolates $/ \mathrm{kg}$ feed) and $100 \mathrm{~g} / \mathrm{kg}$ ground rapeseed $(1.9 \mathrm{mmol}$ glucosinolates $/ \mathrm{kg}$ feed) did not have a negative effect. Glucosinolates caused increased I excreta concentrations (mainly in urine) of mothers and decreased milk I concentration. This resulted in an impaired I and thyroid hormone status of the piglets. Sow diets containing rapeseed feeds are expected to contain no more than $2 \mathrm{mmol}$ glucosinolates $/ \mathrm{kg}$ and at least $1000 \mu \mathrm{g} \mathrm{I} / \mathrm{kg}$ diet should be added, i.e. about twice current German or UK recommended levels. Milk I concentration clearly indicated a high I intake level but serum $\mathrm{T}_{4}$ concentration was a useless diagnostic criterion.

\section{Acknowledgements}

The authors wish to acknowledge the assistance of $\mathrm{Mr}$ Hartmut Burgold, Mrs Carmen Kinast and Mrs Heike Bergmann. This study was supported by the Federal Ministry of Nutrition, Agriculture and Forests, Bonn, Germany (project no. $93 \mathrm{HF}$ 025) and the Union for Promotion of Oil and Protein Plants, Bonn, Germany. Dr George D. Hill from Lincoln University, Canterbury, New Zealand read the paper and gave valuable advice.

\section{References}

Agricultural Research Council (1981) The Nutrient Requirement of Pigs. Slough: Commonwealth Agricultural Bureaux.

Ajjan RA, Kamaruddin NA, Crisp M, Watson PF, Ludgate M \& Weetman AP (1998) Regulation and tissue distribution of the human sodium iodide symporter gene. Clinical Endocrinology 49, 517-523.

Bassler R \& Buchholz H (1993) Die Chemische Untersuchung von Futtermitteln (The Chemical Analysis of Feeds). Darmstadt: VDLUFA Verlag, Band II.

Bell JM (1984) Nutrients and toxicants in rapeseed meal: A review. Journal of Animal Science 58, 996-1010.

Bourdon D \& Aumaitre A (1990) Low glucosinolate rapeseeds and rapeseed meals: effect of technological treatments on chemical composition, digestible energy content and feeding value for growing pig. Animal Feed Science and Technology 30, 175-191.

Campbell LD, Slominski BA, Falk KC \& Wang Y (1999) Lowglucosinolate canola in laying hen diets. In Proceedings of the 10th International Rapeseed Congress [Groupe Consultatif International de Recherche sur le Colza, GCIRC, editors]. Paris: GCIRC.

Danielsen V, Eggum BO, Rasmussen KW \& Sørensen H (1987) Long-term studies of requirements to the quality of rapeseed meal from double low varieties used in sow diets. In Proceedings of the 7th International Rapeseed Congress, vol 7, pp. 1727-1734 [J Krzymanski, editor]. Poznan: Plant Breeding and Acclimatization Institute.

Deutsche Landwirtschaftsgesellschaft (1991) DLG-Futterwerttabellen Schweine (DLG Feed Tables, Pigs), 6th ed. Frankfurt am Main: DLG-Verlag.

Devilat J \& Skoknic A (1971) Feeding high levels of rapeseed meal to pregnant gilts. Canadian Journal of Animal Science 51, 715-719.

Di Stefano J \& Sapin V (1987) Fecal and urinary excretion of six iodothyronines in the rat. Endocrinology 121, 1742-1750.

Drochner W (1989) Einflüsse von Fettzulagen an Sauen auf
Aufzuchtleistung und Fruchtbarkeit (Effects of additional fat for sows on rearing performance and fertility). Übersichten Tierernährung 17, 99-138.

Etienne M \& Dourmad JY (1994) Effects of zearalenone or glucosinolates in the diet on reproduction in sows: A review. Livestock Production Science 40, 99-113.

European Community (1990) Oilseeds - determination of glucosinolates - high performance liquid chromatography. Official Journal of European Commission L170, 27-34.

European Community (1999) Commission Regulation (EC) No. 2316/1999 of 22 October 1999 laying down detailed rules for the application of Council Regulation (EC) No. 1251/1999 establishing a support system for producers of certain arable crops. Official Journal of the European Community L280, 4365.

Fecher PA, Goldmann I \& Nagengast A (1998) Determination of iodine in food samples by inductively coupled plasma mass spectrometry after alkaline extraction. Journal of Analytical Atomic Spectrometry 13, 977-982.

Fenwick GR (1984) Rapeseed as an animal feedingstuff - The problems and analysis of glucosinolates. Journal of the Association of Public Analysts 22, 117-227.

Fenwick GR, Griffiths NM \& Heaney RK (1983) Bitterness in brussels sprouts (Brassica oleracea L var. gemmifera): The role of glucosinolates and their breakdown products. Journal of the Science of Food and Agriculture 34, 73-80.

Gesellschaft für Ernährungsphysiologie (1987) Energie-und Nährstoffbedarf landwirtschaftlicher Nutztiere. Schweine (Energy and Nutrient Requirements of Farm Animals. Pigs). Frankfurt (Main): DLG-Verlag.

Gürtler H, Körber R, Pethes G \& Furcht G (1982) Jodmangel und Schilddrüsenfunktion bei Mutterschweinen und deren Nachkommen (Iodine deficiency and thyroid function of sows and their offspring). In Mengen-und Spurenelemente, vol 2, pp. 363-372 [M Anke, editor]. Leipzig: University of Leipzig.

Jahreis G, Richter GH, Hartung H, Flachowsky G \& Lübbe H (1995) Einsatz von Rapskuchen in der Milchviehfütterung und Auswirkungen auf die Milchqualität (Use of rapeseed cake in dairy cow feeding and influence on milk quality). Das Wirtschaftseigene Futter - Forage 41, 99-114.

Jongen WM (1996) Glucosinolates in Brassica: occurrence and significance as cancer-modulating agents. Proceedings of the Nutrition Society 55, 433-446.

Kohler H, Taurog A \& Dunford HB (1988) Spectral studies with lactoperoxidase and thyroid peroxidase: Interconversions between native enzyme, Compound II, and Compound III. Archiv of Biochemistry and Biophysics 264, 438-439.

Kraft W \& Dürr UM (1996) Klinische Labordiagnostik in der Tiermedizin (Laboratory diagnosis in veterinary medicine). 4th ed., p. 360. Stuttgart, Germany and New York, NY: Schattaner Verlagsgesellschaft.

Lange R, Petrzika M \& Linow F (1986) Zur Kenntnis der Schwefelverbindungen in Raps- (Brassica napus) Varietäten und Verarbeitungsprodukten. 2 Mitt.: Enzymatische Spaltung von Glucosinolaten, Isolierung und gaschromatographischmassenspektrometrische Identifizierung der entstehenden Aglucone (About sulphur compounds in rapeseed (B napus) varieties and processing products. 2nd communication. Enzymatic cleavage of glucosinolates, isolation and gas chromatographic-mass spectrometric identification of aglucones). Die Nahrung 30, 1039-1042.

Lüdke H \& Schöne F (1988) Copper and iodine in pig diets with high glucosinolate rapeseed meal. 1. Performance and thyroid hormone status of growing pigs fed a diet with copper sulphate solution treated or untreated rapeseed meal and supplements of iodine copper or a quinoxaline derivative. Animal Feed Science and Technology 22, 33-43. 
Lüdke H \& Schöne F (1994) Prüfung von Rapskuchen im Verdauungsversuch mit Schweinen (Testing of rapeseed cake in digestibility experiment with pigs). In Proceedings of the 106th Congress of VDLUFA (Verband der Landwirtschaftlichen Untersuchungs- und Forschungsanstalten), pp. 963-966 [H Zarges, editor]. Darmstadt: VDLUFA Verlag.

Maheshwari PN, Stanley DW, Beveridge TJ \& Van de Voort FR (1981) Localization of myrosinase (thioglucoside glucohydrolase, EC 3.2.3.1) in cotelydon cells of rapeseed. Journal of Food and Biochemistry 5, 39-61.

Miller JK, Swanson EW \& Spalding GE (1974) Iodine absorption, excretion, recycling and tissue distribution in the dairy cow. Journal of Dairy Science 58, 1578-1593.

National Research Council (1997) Nutrient Requirement of Swine, 10th ed. Washington, DC: National Academy of Science.

Nürnberg, Karin, Kracht W \& Nürnberg G (1994) Zum Einfluß der Rapskuchenfütterung auf die Schlachtkörper- und Fettqualität beim Schwein (The influence of rapeseed-cake in the rations for growing-finishing pigs on carcass value and fat quality). Züchtungskunde 66, 230-241.

Oginsky EL, Stein AE \& Greer MA (1965) Myrosinase acitivity in bacteria as demonstrated by the conversion of progoitrin to goitrin. Proceedings of the Society of Experimental Biology and Medicine 119, 360-364.

Paik IK, Robblee AR \& Clandinin DR (1980) The effect of sodium thiosulfate and hydroxo-cobalamin on rats fed nitrilerich or goitrin-rich rapeseed meals. Canadian Journal of Animal Science 60, 1003-1013.

Rillema JA \& Rowady DL (1997) Characteristics of prolactin stimulation of iodide uptake into mouse mammary gland explants. Proceedings of the Society of Experimental Biology and Medicine 215, 366-369.

Röhnisch H-G, Knape G \& Becker J (1987) Qualitätsanforderungen für Mischfuttermittel, Wirk- und Mineralstoffmischungen und wissenschaftliche Empfehlungen für den Einsatz in der Tierproduktion (Quality Requirements of Compound Feeds and Mineral Vitamin Premixes and Feeding Recommendations in Animal Production). Leipzig: Agrabuch.

Rowan TG, Lawrence TLJ \& Kershaw SJ (1991) Effects of dietary copper and probiotic on glucosinolate concentrations in ileal digesta and in faeces of growing pigs given diets based on rapeseed meals. Animal Feed Science and Technology 35, 247258.

Rudolph B (1993) Zur Bestimmung von Thiocyanat im Serum mittels HPLC (Determination of thiocyanate in serum by HPLC). In Proceedings of the 105th Congress of VDLUFA (Verband der Landwirtschaftlichen Untersuchungs- und Forschungsanstalten), pp. 677-679 [H Zarges, editor]. Darmstadt: VDLUFA Verlag.

Rundgren M (1983) Low-glucosinolate rapeseed products for pigs - a review. Animal Feed Science and Technology 9, 239-262.

Schöne F, Groppel B, Hennig A, Jahreis G \& Lange R (1997a) Rapeseed meals, methimazole, thiocyanate and iodine affect growth and thyroid. Investigations into glucosinolate tolerance in the pig. Journal of the Science of Food and Agriculture 74, 69-80.

Schöne F, Hartung H, Jahreis G, Graf T \& Tischendorf F (1998a) Prüfung fett-reicher Rapsfuttermittel (Saat und Kuchen) an Zuchtsauen - Futteraufnahme, Aufzuchtergebnisse und Milch (fett) zusammensetzung (Evaluation of high fat rape feeds (seed and cake) on breeding sows - Feed intake, rearing results and milk fat composition). Journal of Animal Physiology and Animal Nutrition 79, 184-197.

Schöne F, Jahreis G, Lange R, Seffner W, Groppel B, Hennig A \& Lüdke H (1990) Effect of varying glucosinolate and iodine intake via rapeseed meal diets on serum thyroid hormone level and total iodine in the thyroid in growing pigs. Endocrinologia Experimentalis 24, 415-427.

Schöne F, Jahreis G, Lüdke H, Groppel B, Kirchner E \& Bock HD (1986) Hypothyreose bei Sauen und Ferkeln nach Fütterung einer Kartoffel-Rapsextraktionsschrotsilage (Hypothyroidism of sows and their piglets after feeding of potato-rapeseedmeal ensilage). Archiv für Experimentelle Veterinärmedizin 40, 507-519.

Schöne F, Leiterer M \& Jahreis G (1998) The effect of rapeseed and rapeseed press cake with different glucosinolate content on sows and their piglets. Recent Advances of Research in Antinutritional Factors in Legume Seeds and Rapeseed. In Proceedings of the Third International Workshop on 'Antinutritional Factors in Legume Seeds and Rapeseed', EAAP publication, no 93, pp. 213-216 [AJM Jansman, GD Hill, J Huisman and AFB van der Poel, editors]. Wageningen: Wageningen Pers.

Schöne F, Leiterer M, Jahreis G \& Rudolph B (1997b) Effect of rapeseed feedstuffs with different glucosinolate content and the iodine administration on the gestating and lactating sow. Journal of Veterinary Medicine A 44, 325-339.

Schöne F \& Paetzelt H (1987) Feeding of high glucosinolate rapeseed meal or administration of potassium thiocyanate and excretion of $\mathrm{SCN}^{-}$in the urine of growing pigs. In Proceedings of the 7th International Rapeseed Congress, vol 7, pp. 1735-1741 [J Krzymanski, editor]. Poznan: Plant Breeding and Acclimatisation Institute.

Schöne F, Rudolph B, Kirchheim U \& Knapp G (1997c) Counteracting the negative effects of rapeseed and rapeseed press cake in pig diets. British Journal of Nutrition 78, $947-$ 962.

Schuld FW \& Bowland JP (1968) Dietary rapeseed meal for swine reproduction. Canadian Journal of Animal Science 48, 57-64.

Spiegel C, Besetti GE, Rossi GL \& Blum JW (1993) Normal circulating triiodothyronine concentrations are maintained despite severe hypothyroidism in growing pigs fed rapeseed presscake meal. Journal of Nutrition 123, 1554-1561.

Spitzweg C, Joba W, Eisenmenger W \& Heufelder AE (1998) Analysis of human sodium iodide symporter gene expression in extrathyroidal tissues and cloning of its complementary deoxyribonucleic acids from salivary gland, mammary gland, and gastric mucosa. Journal of Clinical Endocrinology and Metabolism 83, 1746-1751.

Steel GG \& Torrie JH (1980) Principles and Procedures of Statistics, 2nd ed. pp. 186-187. New York and Toronto: McGraw-Hill Inc.

Taurog A (1985) Hormone synthesis: thyroid iodine metabolism. In Werner's the Thyroid, 5th ed., pp. 53-97. [SH Ingbar and LE Braverman, editors]. Philadelphia PA: JB Lippincott Company.

Thomas L (1995) Labor und Diagnose: Indikation und Bewertung von Laborbefunden für die medizinische Diagnostik (Laboratory and diagnosis: Indication and Evaluation of Laboratory Findings for the Medical Diagnosis). 4th ed. [L Thomas, editor]. Marburg: Die Medizingesellschaft.

Tiran B, Rossipal E, Tiran A \& Lorenz O (1993) Selenium and iodine concentration in human milk and milk formulas in Styria, Austria. In Trace Elements in Man and Animals, pp. 1058-1061 [M Anke, D Meissner and CF Mills, editors]. Gersdorf: Verlag Media Touristik.

Tischendorf F, Kirchheim U, Leiterer M \& Schöne F (1998) Beurteilung von Rapskuchen im Experiment mit wachsenden Schweinen (Evaluation of rapeseed press cake in experiments with growing pigs). Proceedings of the Society of Nutrition Physiology 7, 44. 